\title{
Humic substances, purified MAP and hydrogel in the development and survival of Eucalyptus urograndis
}

\author{
Rodrigo J. da Silva ${ }^{1}$, José M. Ferreira Junior ${ }^{2}$, Flavia A. Silva ${ }^{2}$, \\ Antonio C. M. dos Santos 2 , Saulo de O. Lima² \& Rubens R. da Silva ${ }^{3}$ \\ ${ }^{1}$ Instituto Federal de Educação, Ciência e Tecnologia do Tocantins. Formoso do Araguaia, TO. E-mail: rodrigo.silva@ifto.edu.br (Corresponding author) \\ ${ }^{2}$ Universidade Federal do Tocantins/Pós-Graduação em Produção Vegetal. Gurupi, TO. E-mail: juniortecagrofloresta11@hotmail.com; viih_gpi@hotmail.com; \\ antoniocarlos.uft@hotmail.com; saulolima@uft.edu.br \\ ${ }^{3}$ Universidade Federal do Tocantins/Pós-Graduação em Ciências Florestais. Gurupi, TO. E-mail: rrs2002@uft.edu.br
}

\section{Key words:}

electrical conductivity

hydration

immersion

\begin{abstract}
A B S T R A C T
The development and survival of Eucalyptus urograndis plants may be influenced by products based on humic fractions of the organic matter, purified MAP and soil conditioners, such as hydrogel. Thus, the present study aimed to evaluate the effect of the commercial products Fertiactyl', based on humic substances, purified MAP and hydrogel on the post-planting development and survival of Eucalyptus urograndis. The experiment was conducted in a randomized block design, with 25 treatments and four replicates, each of which consisted of 6 plants. The immersion of the tubes in solution with doses of Fertiactyl and purified MAP promoted the increase in the development and survival of the plants. In the preparation of the hydrogel, the use of solution based on Fertiactyl ${ }^{\circ}$ and purified MAP reduced the hydration capacity of the water-retaining polymer. With increasing doses, there was a linear increment in the electrical conductivity of the solution, exponentially reducing the hydration capacity of the polymer.
\end{abstract}

\section{Palavras-chave:}

condutividade elétrica hidratação imersão

\section{Substâncias húmicas, MAP purificado e hidrogel no desenvolvimento e sobrevivência de Eucalyptus urograndis}

\section{R E S U M O}

O desenvolvimento e a sobrevivência de plantas de Eucalyptus urograndis podem ser influenciados por produtos à base de frações húmicas da matéria orgânica, MAP purificado e condicionadores de solo, como hidrogel; assim, realizou-se o presente trabalho com o objetivo de avaliar o efeito dos produtos comerciais Fertiactyl à base de substâncias húmicas, MAP purificado e hidrogel no desenvolvimento e na sobrevivência em pósplantio de Eucalyptus urograndis. O experimento foi conduzido em delineamento de blocos casualizados com 25 tratamentos e quatro repetições sendo cada repetição uma parcela composta por 6 plantas. A imersão dos tubetes em solução com doses de Fertiactyl e MAP purificado promoveu o aumento no desenvolvimento e na sobrevivência das plantas. No preparo do hidrogel a utilização de solução à base de Fertiactyl e MAP purificado reduziram a capacidade de hidratação do polímero hidro-retentor; com o aumento das doses houve aumento linear na condutividade elétrica da solução fazendo com que a capacidade de hidratação do polímero fosse reduzida exponencialmente. 


\section{INTRODUCTION}

Humic substances originate from the oxidation and polymerization of organic matter and may vary depending on the origin material, extraction method and different concentrations they are found in, with high molecular masses and varied functional groups; thus, growth-regulating compounds can be associated with these structures and can influence plant growth and development (Rosa et al., 2009). Many authors observed increments in morphological parameters in various crops, testing products based on humic substances.

Zandonadi \& Busato (2012) and Zandonadi et al. (2013; 2014) cite that humic substances can activate root and leaf development, increase in the absorption of nutrients and regulation of enzymes that govern plant metabolism, such as $\mathrm{H}^{+}$-ATPase and nitrate-reductase, and protons pumps are essential for the absorption of nutrients by plants. Canellas et al. (2008) also described the occurrence of an auxinic action present in the humic substance.

As to the aspects related to water in the soil, Bernardi et al. (2012) claim that the water-retaining polymer, known by the generic term hydrogel, has been commercialized with the justification of retaining for a longer time water and fertilizers, which are slowly released to the plant. According to Ferreira et al. (2014), hydrogel is an available technology of water replenishment to plants; on the other hand, Aouada et al. (2008) claimed that the presence of nutrients in the solution may compromise the entry of water into the polymeric networks, because the degree of swelling is favored by the strong attractive interactions between the chemical structures of the polymer and the water.

In this context, this study aimed to evaluate the effect of the commercial products Fertiactyl ${ }^{\circ}$, based on humic substances, purified MAP and hydrogel on the post-planting development and survival of Eucalyptus urograndis.

\section{Material AND Methods}

The experiment was carried out at the experimental farm of the Federal University of Tocantins - UFT, Campus of Gurupi-TO, Brazil (11 $43^{\circ}$ S; 49 04 W; 280 m). According to the classification of Köppen (1948), the climate in the region is B1wA'a', humid with moderate water deficiency, defined as hot and humid tropical with rainy season in the summer and dry season in the winter.

Clones of the hybrid Eucalyptus urograndis were used in the experiment and the seedlings were obtained with 120 days of age, from a commercial nursery ('Viveiros Tocantins') located on the Highway TO 342 - Km 2, Miracema do Tocantins-TO. Planting was performed at the spacing of $2 \mathrm{~m}$ between rows and $1.5 \mathrm{~m}$ between plants.

The experiment was set in a randomized block design with four replicates, each of which consisted of a plot with six plants. The 25 treatments were arranged in a factorial scheme with two factors ( $5 \times 5$ ): Factor 1 corresponding to five application methods and Factor 2, five doses of humic substance, from the commercial product - Fertiactyl $l^{\circ}$ and purified MAP $(0,2.5$,
5.0, 7.5 and $\left.10 \mathrm{~mL} \mathrm{~L}^{-1}\right)$. The application methods were adopted based on technical visits in traditional cultivation areas of the forest sector and nurseries of the region, and consisted of:

Method 1 - Immersion of tubes in solution with doses of Fertiactyl ${ }^{\circ}+10 \mathrm{~mL} \mathrm{~L}^{-1}$ of purified MAP in each dose of Fertiactyl;

Method 2 - Immersion of tubes in solution with doses of Fertiactyl;

Method 3 - Immersion of tubes in solution with doses of Fertiactyl ${ }^{\circ}$ and use of hydrated hydrogel with doses of Fertiactyl;

Method 4 - Use of hydrated hydrogel with doses of Fertiactyl;

Method 5 - Use of hydrated hydrogel at the doses of $0,2.5$, 5.0, 7.5 and $10 \mathrm{~mL} \mathrm{~L}^{-1}$ of purified MAP.

In Methods 1 and 2, in order to test the effect of source of humic substances on the post-planting development and survival of Eucalyptus urograndis through the immersion of tubes in solution with different doses of humic substances, irrigation was suspended with antecedence of $16 \mathrm{~h}$, from 6 p.m. to 10 a.m. of the next day. After this period, the following procedure was performed:

Immersion of tubes: Performed in a container with capacity for $2 \mathrm{~L}$ of solution, using two tubes at a time, for $10 \mathrm{~s}$, and after each immersion the volume absorbed by the substrate was replenished and the solution agitated.

The water-retaining polymer was hydrated at the moment of planting, at the proportion of $2 \mathrm{~g}$ of polymer per liter of solution or water, depending on the added treatment, gradually and carefully not to form lumps. Then, it remained for $30 \mathrm{~min}$ for hydration and $0.5 \mathrm{~L}_{\text {plant }}{ }^{-1}$ was applied at planting.

Along the $30 \mathrm{~min}$, there was a reduction in the hydration capacity in the presence of Fertiactyl and purified MAP. Hence, solutions with the same doses of Fertiactyl and purified MAP were prepared at the laboratory and subjected to the determination of electrical conductivity (EC) and hydration capacity. For this, volumes of $500 \mathrm{~mL}$ were prepared at each concentration/dose and, after $5 \mathrm{~min}$ of slow agitation and repose for $2 \mathrm{~min}$, the $\mathrm{EC}$ of the solution was measured using a conductivity meter.

After measuring EC, $1 \mathrm{~g}$ of the water-retaining polymer was added to the solution corresponding to each dose of Fertiactyl and purified MAP, remaining in repose for $2 \mathrm{~h}$ for hydration. Then, the material was sieved through a $0.149-\mathrm{mm}$ mesh.

The drained solution, i.e., the part that did not hydrate, was subtracted from the initial volume corresponding to $500 \mathrm{~mL}$ and the difference was quantified as the capacity of the polymer to retain solution at the different doses of the source of humic substance and purified MAP, according to the following equation:

$$
\mathrm{RET}=\mathrm{ST}-\mathrm{SD}
$$

where:

RET - retention of the solution;

ST - total volume of the solution; and,

SD - volume of the drained solution. 
The indicators used to measure the post-planting survival and development of Eucalyptus urograndis were: collar diameter, measured using a digital caliper, at height of $1.0 \mathrm{~cm}$ from the soil surface; and plant height, measured using $50-\mathrm{cm}$ graduated ruler, from the soil surface to the apical meristem.

The mentioned indicators were used to calculate the mean increment in collar diameter (MICD) and mean increment in plant height $(\mathrm{MIPH})$, calculated by the difference between the values measured at planting and 20 days after; then, plants were counted for the evaluation of survival percentage.

The obtained data were subjected to regression analysis, evaluating the significances of beta coefficients and coefficients of determination, using the program Statistic (Version 7.0). Regression graphs were plotted using the statistical program SigmaPlot (Version 10).

\section{Results AND Discussion}

The mean increment in collar diameter (MICD) in Methods 1 and 2 showed significant quadratic response to the different doses of humic substances (Fertiactyl $1^{\circ}$ ) and the source + purified MAP; in Method 1, the response was increasing until the maximum dose and, in Method 2, the MICD reached $0.64 \mathrm{~mm}$ at the dose of $9.23 \mathrm{~mL} \mathrm{~L}^{-1}$ of the commercial product Fertiactyl $^{\circ}$ (Figure 1).

Positive effects of MAP associated with humic substances were also observed by Duarte et al. (2013), working with MAP sources coated with humic acid, in which conventional MAP, applied to the soil, at the dose of $100 \mathrm{~kg} \mathrm{ha}^{-1}$ of $\mathrm{P}_{2} \mathrm{O}_{5}$, varied from 2.67 to $2.40 \mathrm{mg} \mathrm{dm}^{-3}$ of $\mathrm{P}$, in the presence and absence of coating, respectively. According to Canellas et al. (2008), humic substances have auxinic action. This is in agreement with Silva et al. (2011), who reported, as the main physiological effect, the increase in root development, according to the species, plant age, source and concentration. According to Casimiro et al. (2001), this phytohormone activates the division of pericycle cells, acting on the initial stages of formation of the root primordium, directly influencing root development, which may have affected the mean increments in collar diameter and plant height observed in the present study.

The mean increment in plant height (MIPH) in method 1 showed increasing linear response with the increase in

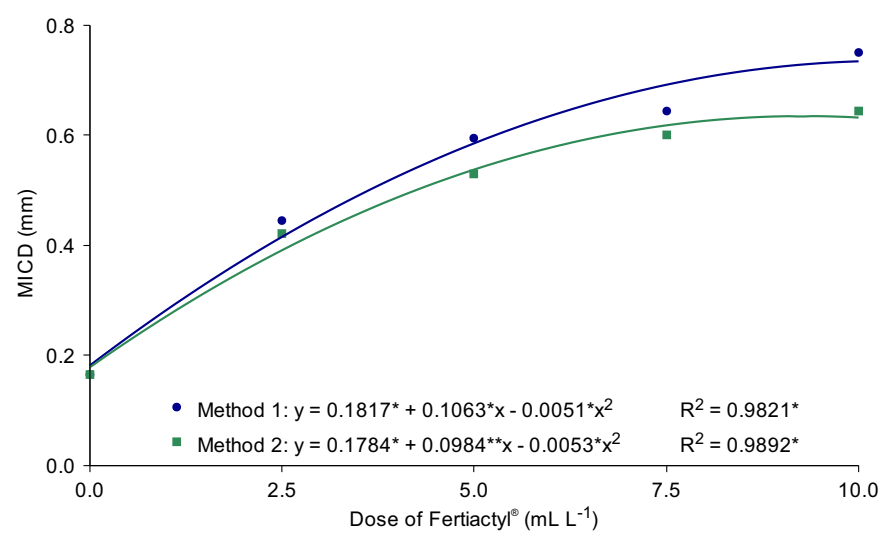

Figure 1. Mean increment in collar diameter (MICD) as a function of doses of the source of humic substances $\left(\right.$ Fertiactyl $\left.\mathrm{I}^{\oplus}\right)+10 \mathrm{~mL} \mathrm{~L}^{-1}$ of purified MAP applied through immersion of the tubes the doses of humic substances and, in Method 2, significant quadratic response, with maximum value of $1.99 \mathrm{~cm}$ at the dose of $8.23 \mathrm{~mL} \mathrm{~L}^{-1}$ of the commercial product Fertiactyl (Figure 2).

Different from the positive result in the promotion of post-planting development in the present study, Pinheiro et al. (2010) reported decrease in the total dry matter of Eucalyptus urograndis seedlings. The negative effect observed by the authors is associated with the calibration of the applied doses of humic acids, which were higher than $10 \mathrm{~mL} \mathrm{~L}^{-1}$ of the source of humic acid. For Baldotto et al. (2014), the use of humic substance for better development must be at adequate concentrations for each plant species, evidencing the importance of calibrating the doses per plant species and development stage.

In the survival analysis, Methods 1 and 2 showed the best responses in relation to the others. In Method 2, the increase in the doses of the commercial product Fertiactyl ${ }^{\circ}$ promoted greater survival, showing the best response at the doses of 5 and $7.5 \mathrm{~mL} \mathrm{~L}^{-1}$. In Methods 3, 4 and 5, in which the hydrogel was prepared with solution based on Fertiactyl ${ }^{\circ}$ and purified MAP, the increase in the doses caused a negative response, reducing plant survival (Figure 3 ).

It is supposed that the ions present in the solution have formed bonds with the water-retaining polymer, making difficult its hydration and rehydration, compromising the

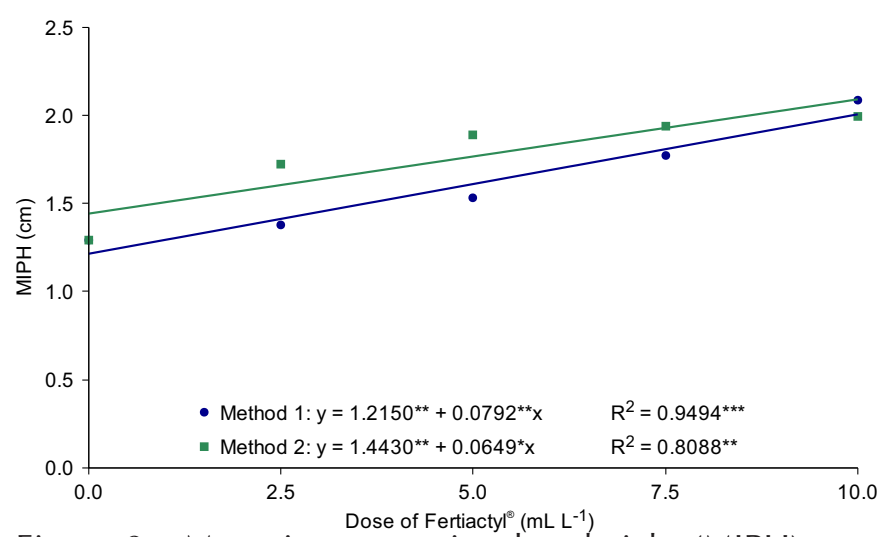

Figure 2. Mean increment in plant height $(\mathrm{MIPH})$ as a function of doses of humic substances of the commercial source Fertiactyl ${ }^{\oplus}$ and Fertiacty $\left.\right|^{\oplus}+10 \mathrm{~mL} \mathrm{~L}^{-1}$ of purified MAP, applied through immersion of the tubes

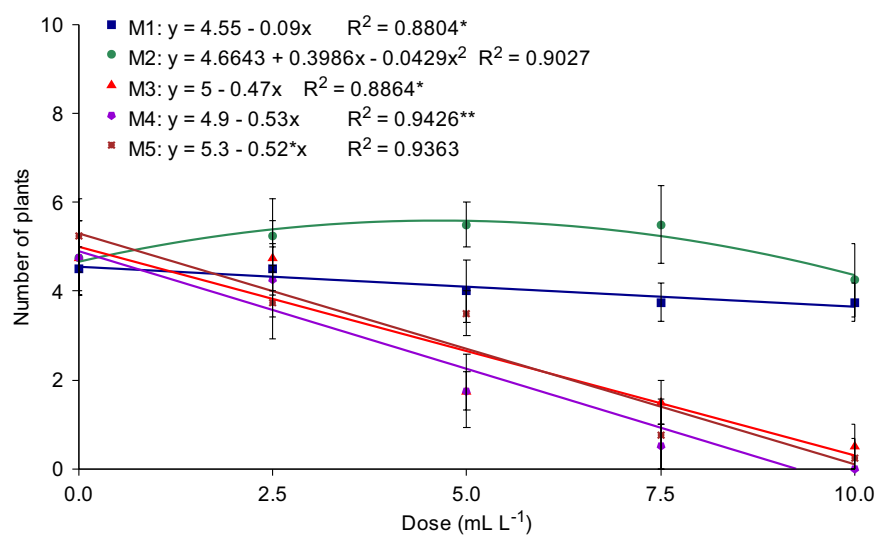

Figure 3. Survival of Eucalyptus urograndis seedlings at 30 days after planting in a Red Yellow Latosol as a function of doses and methods of application of Fertiacty $l^{\circledR}$ and purified MAP 
availability of water immediately after the planting of the seedlings; therefore, the addition of hydrogel in the solution based on Fertiactyl ${ }^{\circ}$ and purified MAP, as a function of saline concentration, may have damaged the polymeric chains, compromising the capacity of contraction/expansion and, as a consequence, negatively interfering with the hydration of the water-retaining polymer. This observation becomes more consistent with the evaluation of the electrical conductivity of the solution at the different concentrations of Fertiactyl and purified MAP (Figure 4), which probably caused the negative effect on the hydration of the water-retaining polymer, due to the interference of the entry of the water molecule into the polymeric networks. Thus, for obtaining positive effects with the use of hydrogel, purified MAP and sources of humic substances, attention should be paid to the capacity of charges in the water-retaining polymer.

The probable effects of electrical conductivity on the hydration of the water-retaining polymer (Figure 4) showed decreasing exponential response as a function of the increase in the doses of Fertiactyl ${ }^{\circ}$ and purified MAP under the studied conditions (Figure 5).

Similar results of negative effect of electrical conductivity of nutrient solution with ferrous sulfate, magnesium sulfate, zinc sulfate, ammonium sulfate and copper sulfate on the retention capacity of the polymer polyacrylamide were reported by Azevedo et al. (2006). In this context, Saad et al. (2009), comparing soils with different textures, observed higher concentrations of $\mathrm{Ca}^{2+}$ and $\mathrm{Mg}^{2+}$ in clayey soil, which according to the authors may have harmed the properties of the hydrogel

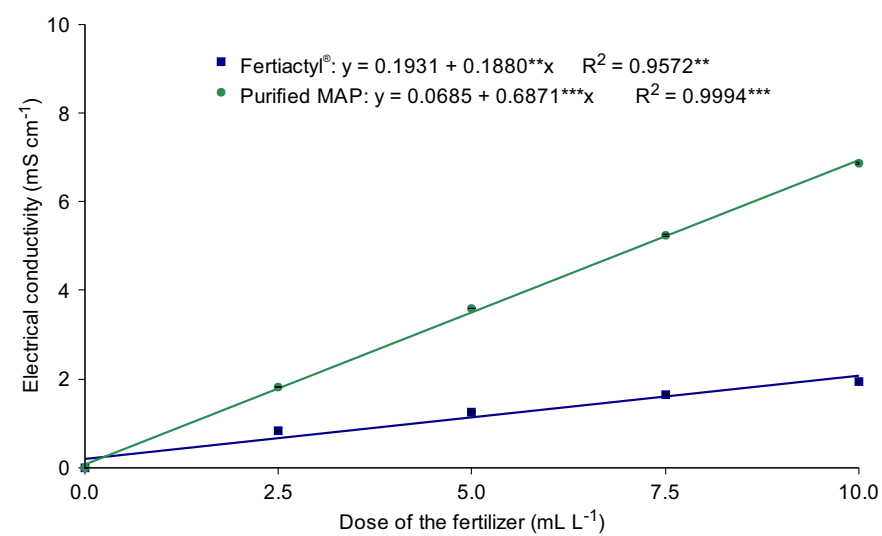

Figure 4. Electrical conductivity as a function of doses of Fertiactyl ${ }^{\varpi}$ and purified MAP

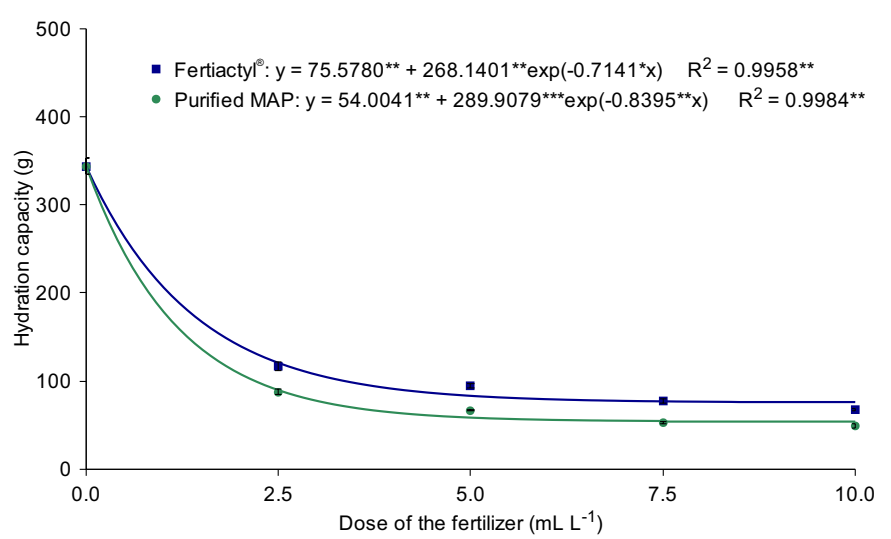

Figure 5. Hydration capacity (g) in $500 \mathrm{~mL}$ of solution as a function of doses of Fertiactyl ${ }^{\oplus}$ and purified MAP and decreased its water retention capacity, worsening water stress and increasing the mortality of Eucalyptus urograndis seedlings. Sita et al. (2005) also reported the deterioration of the polymer and the reduction in the hydration capacity in the presence of $\mathrm{Ca}^{2+}, \mathrm{Mg}^{2+}$ and ionic forms of iron, which is in agreement with Bowman et al. (1990), who claimed that, in general, mineral fertilizers contain salts that limit the retention capacity of the polymers.

The use of humic substances in the mixture of fertilizers has great potential, but the positioning of the products in the fertilization management systems still needs to be better researched, because of the variability of the results due to the diversity of sources of humic substances. According to the results, research must be conducted on sources of humic fractions as promoters of the development of Eucalyptus plants and calibration, as well as on the effect of the mixture of products based on humic substances, hydrogel and purified MAP.

\section{Conchusions}

1. The immersion of the tubes in solution with humic substance from the source Fertiactyl ${ }^{\circ}$ and purified MAP promotes the increase in post-planting survival and development of Eucalyptus urograndis.

2. The increment in the concentration of Fertiactyl ${ }^{\circ}$ and purified MAP linearly increased the electrical conductivity of the solution, exponentially reducing the hydration capacity of the polymer.

\section{Literature Cited}

Aouada, F. A.; Moura, M. R. de; Menezes, E. de A.; Nogueira, A. R. de A.; Mattoso, L. H. C. Síntese de hidrogéis e cinética de liberação de amônio e potássio. Revista Brasileira de Ciência do Solo, v.32, p.1643-1649, 2008. http://dx.doi.org/10.1590/S010006832008000400029

Azevedo, T. L. de F.; Bertonha, A.; Freitas, P. S. L.; Gonçalves, A. C. A.; Rezende, R.; Dallacort, R.; Bertonha, L. C. Retenção de soluções de sulfatos por hidrogel de policrilamida. Acta Scientiarum Agronomy, v.28, p.287-290, 2006. http://dx.doi.org/10.4025/ actasciagron.v28i2.1131

Baldotto, L. E. B.; Baldotto, M. A.; Gontijo, J. B.; Oliveira, F. M.; Gonçalves, J. Aclimatação de orquídea (Cymbidium sp.) em resposta à aplicação de ácidos húmicos. Ciência Rural, v.44, p. 830833, 2014. http://dx.doi.org/10.1590/S0103-84782014000500011

Bernardi, M. R.; Sperotto Júnior, M.; Daniel, O.; Vitorino, A. C. T. Crescimento de mudas de Corymbia citriodora em função do uso de hidrogel e adubação. Cerne, v.18, p.67-74, 2012. http://dx.doi. org/10.1590/S0104-77602012000100009

Bowman, D. C.; Evans, R. Y.; Paul, J. L. Fertilizer salts reduce hydration of polyacrylamide gelsa and affect physical properties of gelamend container media. Journal of the American Society for Horticultural Science, v.115, p.382-386, 1990.

Canellas, L. P.; Teixeira Júnior, L. R. L.; Dobbss, L. B.; Silva, C. A.; Médici, L. O.; Zandonadi, D. B.; Façanha, A. R. Humic acids cross interactions with root and organic acids. Annals of Applied Biology, v.153, p.157-166, 2008. http://dx.doi.org/ 10.1111/j.17447348.2008.00249.x 
Casimiro, I.; Marchant, A.; Bhalerao, R. P.; Beeckman, T.; Dhooge, S.; Swarup, R.; Graham, N.; Inze, D.; Sandberg, G.; Casero, P. J.; Bennett, M. Auxin transport promotes Arabidopsis lateral root initiation. Plant Cell, v.13, p.843-852, 2001. http://dx.doi. org/10.1105/tpc.13.4.843

Duarte, I. N.; Melo Júnior, H. B. de.; Silva, A. de A.; Lana, R. M. Q.; Pires, M. R. Utilização de ácidos húmicos no revestimento do map. Enciclopédia Biosfera, v.9, p.2084-2091, 2013.

Ferreira, E. A.; Silva, V. A.; Silva, E. A.; Silveira, H. de R. O. Eficiência do hidrogel e respostas fisiológicas de mudas de cultivares apirênicas de citros sob défice hídrico. Pesquisa Agropecuária Tropical, v.44, p.158-165, 2014. http://dx.doi.org/10.1590/S198340632014000200009

Köppen, W. Climatologia: Com um estúdio de los climas de La tierra. New Gersey: Laboratory of Climatology, 1948. 104p.

Pinheiro, G. L.; Silva, C. A.; Furtini Neto, A. E. Crescimento e nutrição de clone de eucalipto em resposta à aplicação de concentrações de C-ácido húmico. Revista Brasileira de Ciência do Solo, v.34, p.1217-1229, 2010. http://dx.doi.org/10.1590/S010006832010000400021

Rosa, C. M. da; Castilhos, R. M. V.; Vahl, L. C.; Castilhos, D. D.; Pinto, L. F. S.; Oliveira, E. S.; Leal, O. dos A. Efeito de substâncias húmicas na cinética de absorção de potássio, crescimento de plantas e concentração de nutrientes em PhaseolusvulgarisL. Revista Brasileira de Ciência do Solo, v.3, p.959-967, 2009. http:// dx.doi.org/10.1590/S0100-06832009000400020
Saad, J. C. C.; Lopes, J. L. W.; Santos, T. A. dos. Manejo hídrico em viveiro e uso de hidrogel na sobrevivência pós-plantio de Eucalyptus urograndisem dois solos diferentes. Engenharia Agrícola, v.29, p.404411, 2009. http://dx.doi.org/10.1590/S0100-69162009000300007

Silva, A. C.; Canellas, L. P.; Olivares, F. L.; Dobbss, L. B.; Aguiar, N. O.; Frade, D. A. R.; Rezende, C. E.; Peres, L. E. P. Promoção do crescimento radicular de plântulas de tomateiro por substâncias húmicas isoladas de turfeiras. Revista Brasileira de Ciência do Solo, v.35, p.1609-1617, 2011. http://dx.doi.org/10.1590/S0100-06832011000500015

Sita, R. C. M.; Reissmann, C. B.; Marques, C.; Oliveira, E.; Taffarel, A. D. Effect of polymers associated with $\mathrm{N}$ and $\mathrm{K}$ fertilizer sources on Dendrathema grandiflorum growth and $\mathrm{K}, \mathrm{Ca}$ and $\mathrm{Mg}$ relations. Brazilian Archives of Biology and Technology, v.48, p.335-342, 2005. http://dx.doi.org/10.1590/S1516-89132005000300002

Zandonadi, D. B.; Busato, J. G. Vermicompost humic substances: Technology for converting pollution into plant growth regulators. International Journal of Environmental Science and Engineering Research, v.3, p.73-84, 2012.

Zandonadi, D. B.; Santos, M. P.; Busato, J.G.; Peres, L.; Façanha A. R. Plant physiology as affected by humified organic matter. Theoretical and Experimental Plant Physiology, v.25, p.12-25, 2013. http://dx.doi.org/10.1590/S2197-00252013000100003

Zandonadi, D. B.; Santos, M. P.; Medici, L. O.; Silva, J. Ação da matéria orgânica e suas frações sobre a fisiologia de hortaliças. Horticultura Brasileira, v.32, p.14-20, 2014. http://dx.doi. org/10.1590/S0102-05362014000100003 